\title{
Economism and commercialization as manifestation of the globalization of higher education
}

\author{
Strihul M. V., Khomeriki O. A., National Aviation University
}

The main point of the article is to disclose the essence of the phenomena of economism and commercialization. Economism is seen as part of globalization of education, a global corporatization of education provides training for the global labour market, using human capital economic theories. As noted by George Spring, the human capital, economists argue that investments in education lead to economic growth, reducing income inequality and increasing employment.

In general, the globalization of higher education is considered as a process of increasing interdependence and convergence of national economics, trade liberalization and market dominated by competition, struggle, transnational education and the commercialization of knowledge, as well as the erosion and disappearance of national boundaries and models of education. Despite the fact that most researchers associate globalization with the increasing influence of the World Bank and Americanization of higher education, globalization of higher education is not linear, and the same process of unification of educational systems.

In modern conditions has acquired a strong relevance to international competition and stratification of higher education is also an increasing competition for social and academic prestige. In the context of this increased institutional crossborder activities and academic mobility, global communications and mobility have created conditions for the emergence of the global higher education market. Consequently, the competition among elite universities is now globally closer to capitalist economic forms.

The economization of education is considered as a component of global education, a global corporatization of education provides training for the global labour market using human capital economic theories.

Such massive development of higher education is associated with a number of factors such as socio-economic and socio-cultural, which are manifested at both macro level of the whole society and the microsocial level of the individual.

It becomes obvious by the fact that in a globalized world, the consumer society is transformed into goods, and the goods that will bring a significant profit with the appropriate investment.

However, commercialization of education is quite dangerous for the classical Institute of education. Because education as another global business trend threatens the institutional framework and its content.

The processes of globalization is greatly affected the emergence and spread of economism and the commercialization in various educational systems, in particular it is proved that they formed a single world information-educational space, the characteristics of which are: the rapid penetration of the globalization trends in the national educational system; integration of educational systems into the world market for educational services and intellectual products; increased competition in the global educational environment.

Keywords: university; sociology of education; consumerism; institute; commodification; local problems; modernization

\section{Економізм і комерціалізація як прояв глобалізації вищої освіти}

\section{Стригуль М. В., Хомерікі О. А., Національний авіаційний університет}

Головний зміст статті полягає в розкритті суті явищ економізму та комерціалізації. Економізм розглядається як складова глобалізації освіти, а глобальне акціонування освіти передбачає навчання для глобального ринку праці з використанням людського капіталу економічних теорій. Як зазначає Дж. Спрінг, економісти людського капіталу стверджують, що інвестиції в освіту призводять до економічного зростання, скорочення нерівності доходів і збільшення зайнятості.

У цілому глобалізація вищої освіти розглядається як процес росту взаємозалежності та конвергенції національних економік, лібералізації торгівлі і ринку, де панують конкуренція, боротьба, транснаціональна освіта й комерціалізація знань, а також розмивання й зникнення національних кордонів і моделей освіти. Незважаючи на те, що більшість дослідників пов'язують глобалізацію з посиленням впливу Світового банку і з американізацією вищої школи, глобалізація вищої освіти не є лінійним і однаковим процесом загальної уніфікації освітніх систем.

Ключові слова: університет; соціологія освіти; консюмеризм; інститут; коммодифікація; локальні проблеми; модернізація

\section{Экономизм и коммерциализация как проявление глобализации высшего образования}

\section{Стригуль М. В., Хомерики Е. А., Национальный авиационный университет}

Главный смысл статьи заключается в раскрытии сути явлений экономизма и коммерциализации. Економизм рассматривается как составляющая глобализации образования, а глобальное акционирование образования предусматривает обучение для глобального рынка труда с использованием человеческого капитала экономических теорий. Как отмечает Дж. Спринг, экономисты человеческого капитала утверждают, что инвестиции в образование 
приводят к экономическому росту, сокращению неравенства доходов и увеличению занятости.

В целом глобализация высшего образования рассматривается как процесс роста взаимозависимости и конвергенции национальных экономик, либерализации торговли и рынка, где господствуют конкуренция, борьба, транснациональное образование и коммерциализация знаний, а также размывание и исчезновение национальных границ и моделей образования. Несмотря на то, что большинство исследователей связывают глобализацию с усилением влияния Мирового банка и с американизацией высшей школы, глобализация высшего образования не является линейным и одинаковым процессом всеобщей унификации образовательных систем.

Ключевые слова: университет; социология образования; консюмеризм; Коммодификация; институт; локальные проблемы; модернизация

Determination of the relevance of the topic and the formulation of a scientific problem in the context of the subject of science.

7 he main point of the article is to disclose the essence of the phenomena of economism and globalization. Economism is seen as a part of globalization of education, a global corporatization of education provides training for the global labour market using human capital economic theories. In general, the globalization of higher education is considered as a process of increasing interdependence and convergence of national economics, trade liberalization and market dominated by competition, struggle, transnational education and the commercialization of knowledge, as well as the erosion and disappearance of national boundaries and models of education.

Statement of a scientific problem. Till 1970 the higher education didn't expand the number of students, teachers and existence of financial resources. According to the World Bank (2010) indicators of coverage of students have grown from $9 \%$ to $14 \%$ from 1965 to 1975 . Around the world, in the countries with the lowest and average level of income developing from $4 \%$ to $7 \%$ and in the countries with high income level from $20 \%$ to $33 \%$. From 1980, however, the state resources for the higher education considerably have been lowered almost in each country. Tertiary expenses for education of one school student as a percentage were per capita cut by GDP from 16,3\% to $77 \%$ in general from 1990 to 2005 . With the low and average level of the countries from $25,9 \%$ to $91 \%$ and the countries with high income level from 39\% to $26 \%$ [4].

Aim of the article is to analyze the concept of higher education, economism and commercialization as manifestation of the globalization of higher education and to justify the methodology for sociological macroanalysis.

Analysis of recent publications.

Before to define the influence of globalization factors on educational system, it's necessary to define a globalization essence as phenomenon of modern society, in concepts of social and humanitarian knowledge of the end of the 20th century term «globalization» became a key, giving a basis for understanding of the new welfare phenomena. However the variety of the ideas, their variety and versatility have caused existence of a research of the

concept «globalization». In general, globalization is considered to be common problems concerning the world and also a consequence of integration processes such as formation of the uniform world market, the distribution of goods, free exchange of goods and capital [5].

The American sociologists M. Castells and P. Evans claim that globalization has significantly changed the nature of the modern national states as the main organizers of accumulation of the capital and as carriers and creators of national identities. Gradual withdrawal of the national state from the higher education was expressed in particular in reduction of the state resources, competition strengthening. Still, traditional autonomy of educational institutions and their experts from the national states and the markets considerably decreases recently [2].

The American philosopher V. Volin expresses the point of view that globalization is a product and, in turn, line, that promotes growth of an economization of the society and the destruction of everything that is considered «public» whereas P. Evans perceives globalization as changes in character and ability of the national states. The American sociologist S. Margenson considers in the last continuous expansion of the markets, in particular in education and productions of knowledge, all this promotes a decrease in trust of society to the universities, institutes which strongly depend on the state resources [2].

The Mexican scientist D. Barriga recognizes globalizations as crisis of publicity and degradation of social trust in education characterizes by expression of constant problems on the way of efficiency, productivity, lack of justice and poor quality of large educational systems.

\section{Presentation of the main results.}

According to the American sociologists Sh. Sloter, L. Lesley, I. Ordorika, globalization in the sphere of the higher education also substantially materializes thanks to the emergence of the new markets and the market relations of higher educational institutions and their «production». Acceptance of market practice or those procedures which try to imitate these practicians (the markets, pseudo-markets or the fictitious markets) became one of the most relevant characteristics of the modern higher education.

It's worth addressing the analysis of hierarchy of higher education in which the last at the global level represents the expression of the imperious relations. In 
this area the elite research universities interact directly with each other within the general global networks, within the national systems of higher education they are closely involved in policy of the government and also react on districts are more localized.

According to the French sociologist P. Bourdieu international field of higher education uneven, hierarchical and constant competing. The universities are located in this area on the basis of their historical circumstances, university traditions and local parameters, in particular, possession of financial and cultural achievements and also through the situation, accepting strategy which also historically caused.

Productivity of researches is fundamental in the creation of the university as institutions at the international and local levels. Their national popularity and influence on state policy depends on the productivity of researches more and more and complicates ability and readiness of this establishment in local problems.

Globalization of higher education has changed the relation to university ratings. Around the world the attention to the ratings of the universities is signed of the new world market. Comparisons reflect and enhance structure of these markets as the systems of the power. In this context of perception of institutional and individual competitions within the international market of the higher education strengthens business presence as practicians and problems. The officials' disturbance is in how to reach higher performance level of researches from the most effective levels of investments into material and human resources that is how to increase the academic productivity.

However, university ratings show rather uneven distribution of resources and the status. The greatest ratings now in the universities in the USA and Great Britain. English arises only global language for carrying out the international researches. More important the fact that national and state committees in support of the higher education take the lesser participation in the international support of the sphere of the higher education and its standards.

According to the Swedish sociologist B. Vitrok, despite great similarities between systems and institutes, in the world, there was no uniform idea of the university. On the contrary, various traditions of the university work at national, global or regional levels. Some models or traditions are defined by national borders or in certain cases post-colonial traditions, another connected with culture or geographical proximity. Even while some of these models have more international influence, than others, all of them represent university traditions.

In this global era in which model, the ideas and policy freely interact through national borders it would be possible to expect that various traditions collectively contribute to the development international the higher education. Tendencies in the field of global standardization partially reflect emergence of the general principles and systems in the sphere of the higher education, but they also reflect cultural and material distinctions and inequalities [1].

It should be noted that in a process which we can designate market or commodifikative higher education has been brought into accord with requirements and practice of the different markets as at the national, and international levels. In this global context the research universities were, deliberately or not, integrated into the world market with the system of the international ratings installed in the center.

Standard measures of scientific work became international homogenizing by force which sends the universities of different origin, traditions and a role in the general process of the competition in unequal conditions and with unequal opportunities for success. Thus, the global market of the higher education works as the powerful mechanism reproducing inequality between various types of higher education institutions from different regions or the countries in extremely differentiated access to the intellectual and material resources.

Reproduction of the world market of higher education is based on two different, but deeply interconnected processes: coordination and hierarchical stratification. Reproduction happens on the basis of standard character of productivity of the focused model and its homogenization of influence on a variety of projects and university traditions.

It's worth noticing that many universities on the periphery of this model, in such countries such as Latin America, have kept the differentiated traditions and play the central role in the development of the national state. Most of them were included in the conflict process of compliance and homogenization of global model. It's very risky transition for the peripheral universities and the countries in which they are based where have entered the process of submission and the unequal competition to foreign model for North America of the research universities and its best institutions.

In this regard, it's essential to consider a variety of regional and national contexts and also the fact that from university traditions, it's impossible to remember any alternative to restriction of the model of predominant force. The central place in this process is taken by reconstruction, social pleasure the higher education on the basis of broader valorization of its contributions to society which are beyond market interactions and performance of administrative practice. Global tendencies suggest to consider the university as:

- $\quad$ exclusive space for an articulation between global tendencies and national originality; potential of local social arrangements and interaction between various cultures and beliefs, various ethnic groups and migrants and also floors, classes and other social distinctions;

unique installation of the public sphere of reflexive understanding and reasonable criticism of modern society and its relations with the environment 


\section{(V. Pusser);}

- the only existing institute in modern society, is capable to overcome a gap between special knowledge and society in general, in the context of society of knowledge and information economy (S. Fuller);

the most valuable establishment of restoration and formation of modern general values and social arrangements and also as the main place of formation of various interactions with society and with his environment;

fundamental establishment for production of knowledge, spheres of social problems including those which are beyond narrow reach of production requirements and requirements of the market address to wide.

It's necessary to notice that in 2007 the German sociologist Y. Krauf in work «Ware Bildung, Schule und Universität unter dem Diktat der Ökonomie» carries out the analysis of the hidden procedure behind a process of education reform of Germany on a constant basis. The scientist notes that the school in the conditions of globalization turns not into social institutions, and into «the service organization» which trains experts for labor market. According to Y. Krauf, schools and the universities work as the business directed to managers instead of teachers and rectors today. The government has ceased to take the responsibility, and corporations dictate the content of education. The students are of a secondary importance. The education becomes goods more [6].

The author considers the above-stated correlations in the context of their final consequences. Based on numerous examples and accurate determination of the terms of real work, it's opened the systems of modern education: new media, university ratings, the comparative analysis and assessment are a part of global, neoliberal attempt to control the sector of education according to the economic principles. As a result, the content of education within the systems of public schools gradually begins to serve economic interests to the detriment of the general education [6]. The systematic review of all connected phenomena and their origin gives complete idea of the impact exerted by the international organizations, such as WTO, the World Bank, multinational corporations (for example by means of ERT - the European round table of industrialists), funds and other global players who control a national educational political debate.

Using personally focused education definition, Y. Krauf also considers the true purposes of education [6]. In a process which happens in interpersonal interaction between the teacher and the pupil education has to keep development of pupils, their independence, analytical skills, compassion and also democratic responsibility. The educational policy has to redirect the attention to service to mankind. Teachers, professor, students and parents are encouraged to reconsider the role and to restore control over an education system [6].

The American sociologist J. Spring in work
«Education globalization» [8] recognizes that the economization of education is a growing influence of economists on a research of education and accuses school of use of economic terms. Economization of education, protection of human rights, environment protection for the economic growth and employment [8]. The scientist claims that the economization of education puts economic value of knowledge, traits of the personality and family life [8].

In this context of J. Spring uses the concept «education corporatisation» in which is told about the multinational corporations influencing global school policy and form behavior of the person for the concrete organization. Besides, global educational corporations want to own school rules which increase sales of their products, for example, of texts, the software, the equipment and online training. These transnational networks carry out the influence through the international organizations, such as OECD, World Economic Forum, World Trade Organization (WTO) and regional trade organizations [8].

According to J. Spring, the globalization of education belongs to worldwide networks, the processes and institutes influencing on local educational practicians and politicians. The word «around the world» is key here, as events take place on a global scale which influences national and local school systems. Global educational policy and practice exist in a superstructure over national and local schools. In modern society, many people prefer to realize the policy of «a global superstructure» to compete in the conditions of global economy [8].

Certainly, it's necessary to agree with the opinion that the main global institutes, influencing worldwide policy in the field of education, the Organization for Economic Cooperation and Development (OECD) the World Bank is; United Nations Educational, Scientific and Cultural Organization (UNESCO) World Trade Organization (WTO) and its General agreement on trade in services (GATS); and other MPO and NGO, such as human rights, ecological and women's organizations. English as a world language of business and tourism also influences local schools, a part of a training program is taught in English.

Economization of education is considered as making education globalizations, and global corporatization of education is provided with training for global labor market with the use of the human capital of economic theories. As is indicated J. Spring, economists of the human capital claim that investments into education lead to economic growth, reduction of inequality of incomes and increase in employment [8].

It should be noted that education market the global economization of education provides application of two types of skills. The first type is the cognitive skills and knowledge necessary for achievement of success in a workplace. Another type is a behavior, necessary for work in the corporate world. Economists claim that preschool education is necessary for development of 
skills of interpersonal communication and formation of traits of character to achieve success in life.

Corporatisation in the context of teaching skills of interpersonal communication means formation of human behavior for satisfaction of requirements of business. The economic paradigm approaches to it which is called «pushing» on the basis of work «Nudge: Improving Decisions about Health, Wealth, and Happiness»» economists R. Taylor and K. Sansteyn where changes provide application by the governments of behavioural economics and social psychology approaches it others to form public behavior [7].

It is worth noticing that in 1985 the economist T. Levitte has entered the term «globalization» for the description of changes in a global economy. Subsequently the term has been quickly applied to political and cultural changes which influence for the whole world. One of these general global phenomena - education and a tuition fee. The first edition of the magazine «Globalisation, Societies and Education» indicate the increasing value of globalization and education as areas of a research of the states. Widespread in modern society formal education. However, the globalization of education doesn't turn all schools in identical.

Non-governmental organizations, such as the United Nations, OECD and the World Bank, put forward discussions about preparation of jobs, economic development and multiculturalism. Modern technologies accelerate the global stream and creation of library of world knowledge. Global nongovernmental organizations, especially those who are engaged in human rights and environment protection, influencing school programs worldwide [3].

It should be noted the main making education globalizations:

- Acceptance by the people similar educational practician, including training programs, school organizations and pedagogies.

- Global discourses which influence local and national educational politicians, school administrators, faculties of higher education institutions and teachers. MPO and NGO which influence on national and local educational practicians. practice.

Global networks, stream of the ideas and

The multinational corporations providing the market of educational product tests, training programs and school materials.

- Global marketing of the higher education and educational services.

- Global information technologies, electronic training and communications.

- Influence of world resettlement of the people on national and local policy and practice of multiculturalism.

Extraordinary influence of English on education, training programs, etc.

- Global models of religious education and education of indigenous people [3, p. 13-20].

In the context of globalization of education it is necessary to pass to consideration of global educational streams, according to A. Appadurai.

Conclusions and perspectives of further exploration in the direction of the topic of the article.

Thus, the above-stated scientists claim that globalization of educational institutes and the practician can be provided as a superstructure, consisting of global flows and networks, and their influence is defined by interpretation, adaptations, or rejection from local teachers.

Therefore, in education treat the key moments of global flows and networks:

- The global stream of the ideas, or ideoscapes that promotes global national educational policy of similarity.

- Networks of the educational politicians working in non-governmental organizations and the World Bank participate in global educational discourses and carry out a contribution to global educational practice.

- Networks of educational politicians and scientists, through e-mail and other forms of Internet communication create scientific publications and international meetings and promote global a stream of the ideas in the field of education and discourses.

- Global capital flow and trade, or financescapes including multinational corporations, marketing educational products and services.

- Wide area networks include those who belong to others of wide area networks, educational politicians and scientists, the staff of non-governmental organizations and multinational corporations which promote a flow of educational discourses and the practice.

\section{БІБІЛІОГРАФІЧНІ ПОСИЛАННЯ}

1. Гидденс Э. Ускользающий мир: как глобализация меняет нашу жизнь / Э. Гидденс. - М.: Весь мир, 2004. $120 \mathrm{c}$.

2. Кастелльс М. Становление общества сетевых структур / М. Кастелльс // Новая постиндустриальная волна на Западе: антология / Под ред. В. Л. Иноземцева. - М.: Академия, 1990. - 232 с.

3. Кльов М. В. Глобалізація освітньої системи, практик та дискурсів крізь призму соціологічних поглядів / М. В. Кльов, О. А. Хомерікі // Соціальні технології: актуальні проблеми теорії і практики: збірник наукових праць. Запоріжжя, 2014. - № 53. - С. 13-20.

4. Лесли Т. Политическая экономия Адама Смита / Т. Лесли. - М.: Прогрес, 1970. - 238 с. 
5. Налетова И. В. Аналитика исследований высшего образования как культуроформирующего фактора современности: дисс. ... доктора филос. наук: 24.00.01 / И. В. Налетова. - Тамбов, 2005. - 304 с.

6. Krauf J. Ware Bildung, Schule und Universität unter dem Diktat der Ökonomie / J.Krauf. - Berlin, 2007. - 196 s.

7. Taylor C. The ethics of authenticity / C. Taylor. - Cambridge, Mass: Harvard University Press, 2003. - 189 p.

8. Spring J. Globalization of Education: An Introduction / J.Spring. - London: Routledge, 2014. - 244 p.

\section{REFERENCES}

1. Giddens, Je. (2004). Uskol'zajushhij mir: kak globalizacija menjaet nashu zhizn'[The escaping world: how globalization is changing our lives]. Moscow: Ves' mir [in Russian].

2. Kastell's, M. (1990). Stanovlenie obshhestva setevyh struktur [The formation of a network society]. Novaja postindustrial'naja volna na Zapade: antologija. V. L. Inozemceva (Eds.). Moscow: Academy [in Russian].

3. Kl'ov, M.V. (2014). Globalizacija osvitn'oï sistemi, praktik ta diskursiv kriz' prizmu sociologichnih pogljadiv [Globalization of the educational system, practices and discourses through the prism of sociological views]. Social'ni tehnologii: aktual'ni problemi teoriï i praktiki', 53, 13-20 [in Ukrainian].

4. Lesli, T. (1970). Politicheskaja jekonomija Adama Smita [The political economy of Adam Smith]. Moscow: Progres [in Russian].

5. Naletova, I.V. (2005). Analitika issledovanij vysshego obrazovanija kak kul'turoformirujushhego faktora sovremennosti [Analytics of Higher Education Studies as a Culture of the Forming Factor of Modernity]. Doctor's thesis. Tambov [in Russian].

6. Krauf, J. (2007). Ware Bildung, Schule und Universität unter dem Diktat der Ökonomie. Berlin.

7. Taylor, C. (2003). The ethics of authenticity. Cambridge, Mass: Harvard University Press.

8. Spring, J. (2014). Globalization of Education: An Introduction. London: Routledge.

\section{Стригуль Марина Василівна}

Кандидат соціологічних наук, доцент

Національний авіаційний університет

02000, м. Київ, проспект Космонавта Комарова, 1

\section{Strihul Marina V.}

$\mathrm{PhD}$ in Sociological Sciences, Associate Professor

National Aviation University

1, Kosmonavta Komarova Ave., 02000, Kyiv, Ukraine

ORCID: 0000-0002-6086-4017

Email: marinka.strigul@gmail.com

\section{Хомерікі Олена А.}

Доктор соціологічних наук, професор

Національний авіаційний університет

02000, м. Київ, проспект Космонавта Комарова, 1

\section{Khomeriki Helen A.}

Doctor of Sociological Sciences, Professor

National Aviation University

1, Kosmonavta Komarova Ave., 02000, Kyiv, Ukraine

ORCID: 0000-0003-3702-0390

Email: Khomeriki.helen@gmail.com

Цитування: Стригуль М. В. Економізм і комерціалізація як прояв глобалізації вищої освіти / М. В. Стригуль, О. А. Хомерікі // Науково-теоретичний альманах «Грані». - 2018. - Т. 21. - № 4. - С. 72-77.

Citation: Strihul, M.V., \& Khomeriki, H.A. (2018). Ekonomizm i komertsializatsiia yak proiav hlobalizatsii vyshchoi osvity [Economism and commercialization as manifestation of the globalization of higher education]. Scientific and theoretical almanac «Grani», 21(4), 72-77. 